\section{MIJEŠANJE KVANTITATIVNOG I KVALITATIVNOG ISTRAŽIVAČKOG PRISTUPA U DRUŠTVENIM ZNANOSTIMA - MIJEŠANJE METODA ILI
METODOLOGIJA?}

SAŽETAK

lako se u svijetu sve češće koristi, mješoviti istraživački pristup u društvenim znanostima u Hrvatskoj još uvijek je rijetkost. Mogući razlog tome leži i u zamršenosti i brojnim nejasnoćama koje se i dalje uz ovaj pristup vežu, poput: miješaju li se u mješovitom pristupu metode ili metodologije? Ako se miješaju metodologije, a ne samo metode, od koje istraživačke paradigme krenuti $i$

${ }^{1}$ Doc. dr. sc. Ivana Sekol, socijalna pedagoginja, e-mail: ivana.sekol.mail@ gmail.com

2 Dr. sc. Ivana Maurović, socijalna pedagoginja, e-mail: ivana.maurovic@erf.hr 3 Ovaj rad nastao je u sklopu projekta IP-2014-09-9515 koji se provodi na Edukacijsko-rehabilitacijskom fakultetu Sveučilišta u Zagrebu, a koji financira Hrvatska zaklada za znanost. Obje autorice suradnice su na projektu, a motivacija za rad nastala je prilikom planiranja mješovitog nacrta istraživanja projekta.
Pregledni članak

Primljeno: ožujak, 2017.

Prihvaćeno: travanj, 2017.

UDK 303

D0I 10.3935/ljsr.v24i1.147

Ivana Sekol ${ }^{1}$

Sveučilište Josipa Jurja Strossmayera u Osijeku

Fakultet za odgojne i obrazovne znanosti

Odsjek za društvene znanosti

Ivana Maurović 2

Sveučilište u Zagrebu

Edukacijsko-rehabilitacijski

fakultet

Odsjek za poremećaje u ponašanju

Ključne riječi:

mješoviti istraživački pristup, miješanje, metode, metodologije. 
koji tip nacrta istraživanja koristiti? Je li moguće miješati različite paradigme koje su u podlozi različitih istraživačkih pitanja?

Cilj ovog rada jest ispitati postoji li način da se podjele mogućnosti miješanja kvalitativnih i kvantitativnih istraživanja pojednostave - posebice s obzirom na vrstu mješovitog pristupa i odgovora na pitanje miješaju li se u svakoj od njih metode ili metodologije. U radu su prvo objašnjena i kritički raspravljena obilježja mješovitog pristupa, vrste nacrta u mješovitom pristupu i paradigmatski izazovi, a zatim je ponuđen prijedlog jednostavnije podjele različitih mogućnosti mješovitog istraživačkog pristupa. Prema navedenom prijedlogu, mješoviti istraživački pristupi mogu se podijeliti na dvije osnovne skupine -jednu koja miješa metode i drugu koja miješa metodologije. Prijedlog jednostavnije podjele mješovitih istraživanja osmišljen je kao svojevrstan vodič prema kojemu, ovisno o istraživačkim pitanjima i/ili hipotezama istraživači mogu odabrati najprikladniji mješoviti nacrt za svoja istraživačka pitanja.

\section{UVOD}

U društvenim istraživanjima razvijenih zapadnih zemalja upotreba mješovitog metodološkog pristupa posljednjih desetljeća sve je češća. Prema Creswell (2009.), tri su osnovna razloga za takav trend. Prvo, razvojem društvenih znanosti istraživački problemi postaju sve kompleksniji pri čemu oslanjanje samo na kvantitativni ili kvalitativni istraživački pristup često nije dovoljno. Drugo, istraživanja u društvenim znanostima u posljednje vrijeme sve su interdisciplinarnija i oko sebe često okupljaju istraživačke timove sastavljene od znanstvenika vrlo različitih metodoloških interesa i vještina što često sugerira korištenje mješovitog pristupa. Treće, kvalitativna i kvantitativna istraživanja kao zasebni pristupi sve su razvijenija i legitimnija što im na određeni način daje dovoljno kredibiliteta za njihovo miješanje.

Dok je u međunarodnim društvenim istraživanjima miješanje kvalitativnih $\mathrm{i}$ kvantitativnih metoda sve češće, u hrvatskim znanstvenim istraživanjima, bilo u području društvenih ili drugih znanosti, mješoviti pristup izuzetno je rijedak. Primjerice, online pretraga Googlea, Google znalca i »Portala znanstvenih časopisa Republike Hrvatske« (HRČAK) korištenjem istih relevantnih ključnih riječi u svakoj od baza identificirala je svega 11 radova temeljenih na mješovitom istraživačkom pristupu (Buć, 2007.; Mašanović, 2011.; Stanić, 2011.; Tafra-Vlahović, 2011.; KisovarIvanda i Batarelo-Kokić, 2012.; Kisovar-Ivanda, 2013., 2014.; Ratkajec Gašević, 2013.; Rukavina, 2014.; Giljević, 2014., 2015.)

\footnotetext{
${ }^{4}$ U svaku od navedenih baza podataka unesene su sljedeće ključne riječi: metodologija mješovitog pristupa; mješoviti pristup u znanstvenim istraživanjima; mješovita metodologija; triangulacija; metodološka triangulacija, kombinirana metodologija i metodologija kombiniranog pristupa. Pretraživanje je provedeno 21.5.2016. godine.
} 
Pri tome, riječ je o radovima koji uključuju pravu metodološku tirangulaciju, a ne triangulaciju podacima. lako je, naravno, moguće da u Hrvatskoj ima nešto više objavljenih radova temeljenih na mješovitom pristupu, a koji nisu dostupni u navedene tri on line baze podataka, ova brza pretraga neminovno pokazuje da u Hrvatskoj znanosti mješoviti istraživački pristup nije popularan. Odgovor na pitanje zašto je to tako najvjerojatnije leži u činjenici da mješoviti pristup nije uvijek jednostavan te da se uz njega vežu brojne nedoumice. Najčešće postavljano pitanje vezano uz upotrebu mješovitog pristupa jest ono koje propituje što se to točno u mješovitom pristupu miješa. ${ }^{5}$ Točnije, miješaju li se metode ili metodologije, odnosno, ako se miješaju metodologije, a ne samo metode, od koje istraživačke paradigme krenuti i koji tip nacrta istraživanja koristiti? Kako će biti detaljnije prikazano u središnjem dijelu ovog rada, opsežna strana metodološka literatura navodi i objašnjava ne samo različite vrste mješovitog pristupa (primjerice, sekvencijalni ili konvergentno paralelni), već i različite mogućnosti miješanja kvalitativnog i kvantitativnog istraživanja (točnije, aparadigmatizam, pristup višestrukih paradigmi i pristup jedinstvenih paradigmi). Međutim, u metodološkoj literaturi nisu u dostatnoj mjeri ponuđeni odgovori na navedena pitanja. Točnije, ne uspijeva se vrste mješovitog pristupa povezati s različitim mogućnostima miješanja kvalitativnih i kvantitativnih istraživanja. Primjerice, prilikom objašnjavanja mogućnosti miješanja kvalitativnog i kvantitativnog istraživanja u literaturi se ne navodi za koju vrstu mješovitog pristupa je svaka pojedina mogućnost najprikladnija, i obrnuto. Također, ne objašnjava se radi li se kod aparadigmatizma, pristupa višestrukih paradigmi i pristupa jedinstvenih paradigmi o mogućem miješanju samo metoda, već se a priori raspravlja pitanje miješanja metodologija, odnosno paradigmi ${ }^{6}$.

lako važne s teorijskog aspekta, spomenute brojne podjele vrsta mješovitog pristupa, kao i napori u objašnjavanju različitih mogućnosti miješanja kvalitativnog i kvantitativnog istraživanja prisutni u metodološkoj literaturi, stoga nemaju veliku praktičnu važnost. Naprotiv, čini se kako takve brojne teorijske i, vrlo često, filozofske podjele i rasprave mješovitog pristupa, ne samo da ne pomažu istraživačima u planiranju mješovitog istraživačkog pristupa, već dodatno kompliciraju važne odluke prilikom takvog planiranja.

\footnotetext{
${ }^{5}$ lako se u literaturi često postavlja i pitanje kako oblikovati istraživačka pitanja u mješovitom pristupu, ovaj rad polazi od pretpostavke da svako istraživanje, pa tako i ono mješovito polazi od istraživačkih pitanja na temelju kojih se onda odabiru metode i pripadajuće im metodologije, a ne obrnuto. Iz navedenog razloga, ovaj rad neće posebno raspravljati pitanje istraživačkih pitanja u mješovitom nacrtu istraživanja.

6 S obzirom da će ovaj rad navedene tri mogućnosti raspraviti u kontekstu vrste mješovitog pristupa, ali i odgovora na pitanje miješaju li se u svakoj od mogućnosti nužno paradigme (metodologije) ili je pak moguće da se radi samo o miješanju metoda, u ovom radu navedene tri mogućnosti neće se a priori smatrati onima u kojima se miješaju paradigme. Zašto se u literaturi paradigme često vežu uz metodologiju, ali ne i uz metode istraživanja, objašnjeno je u sljedećem poglavlju.
} 
Cilj ovog rada stoga jest ispitati postoji li način da se navedene podjele mogućnosti miješanja kvalitativnih i kvantitativnih istraživanja pojednostave - posebice s obzirom na vrstu mješovitog istraživačkog pristupa i odgovora na pitanje miješaju li se u svakoj od njih metode ili metodologije - te da se, ukoliko postoji, time demistificiraju odluke vezane uz planiranje mješovitog istraživanja što bi bilo posebno korisno za manje iskusne istraživače. Specifični ciljevi rada su: 1) kritički raspraviti svaku od pojedinih mogućnosti miješanja kvalitativnih i kvantitativnih pristupa (aparadigmatizam, višestruki pragmatizam i pristup jedinstvenih paradigmi) te za svaku mogućnost: a) navesti najprikladniju vrstu mješovitog pristupa; b) raspraviti radi li se u njenom slučaju o miješanju metoda ili metodologija i c) utvrditi je li riječ uistinu o jedinstvenoj mogućnosti mješovitog pristupa ili postoje preklapanja s nekom drugom mogućnosti; 2) ukoliko se pojedine mogućnosti mješovitog pristupa međusobno preklapaju, predložiti njihovu jednostavniju podjelu koja će moći služiti istraživačima u društvenim znanostima kao svojevrstan jednostavan vodič u planiranju nacrta mješovitog istraživanja.

Kako bi se navedeni ciljevi ostvarili, nužno je prvo dati pregled: 1) osnovnih obilježja i definicija mješovitog pristupa u istraživanjima; 2) vrsta mješovitog pristupa i 3) istraživačkih paradigmi u društvenim znanostima.

\section{OBILJEŽJA I DEFINICIJE MJEŠOVITOG ISTRAŽIVAČKOG PRISTUPA}

Kao što ime sugerira, mješoviti istraživački pristup sastoji se od miješanja kvantitativnog i kvalitativnog pristupa u jednom istraživanju (Este, Sitter i Maclaurin, 2009.). Kvantitativni pristup temelji se na primjeni metoda koje omogućuju kvantificiranje pojava, odnosno njihovo brojčano iskazivanje te generaliziranje zaključaka o uzročnosti na cjelokupnu populaciju. Ovaj pristup dobar je za testiranje teorija, odnosa, identificiranje određenih obrazaca podataka ili čak uspostavljanje uzročno-posljedičnih veza između pojava. Nedostaci kvantitativnog pristupa odnose se na nemogućnost obuhvaćanja konteksta, kao i nemogućnost dovoljno »dubokog« obuhvaćanja svega onog što je potrebno za potpuno razumijevanje socijalne interakcije (Mejovšek, 2013.). Također, s obzirom da je kvantitativno istraživanje deduktivno, rezultati su ograničeni varijablama uključenim u istraživanje. $S$ druge strane, kvalitativni nacrt je induktivan te stvara prilike propitkivati postojeće ideje, razvijati nove teorije i biti otvoren za perspektivu sudionika istraživanja koja nedostaje u kvantitativnim istraživanjima (Guba i Lincoln, 1994.). Glavne poteškoće i problemi s kvalitativnim istraživanjima su pitanje vjerodostojnosti i dosljednosti podataka, pitanje objektivnosti zaključaka te generalizacije rezultata istraživanja (Mejovšek, 2013.).

\section{0 članci}


Neki autori (primjerice, Symonds i Gorard, 2008.) smatraju kako binarna distinkcija između kvantitativnog i kvalitativnog pristupa nije održiva u praksi jer oba pristupa dijele neka zajednička obilježja. Navode kako među istraživačima u društvenim znanostima postoji pogrešna percepcija da su statističke analize tehničke i objektivne, dok su ostale netehničke i subjektivne. Naglašavaju kako je subjektivnost prisutna i u kvantitativnim i u kvalitativnim istraživanjima, a odnosi se kako na subjektivnost sudionika (primjerice, prilikom opisivanja svojih iskustava u intervjuu ili odabiranja odgovora na skali Likertovog tipa) ili istraživača (prilikom odabira pitanja u intervjuu ili konstruiranja mjernog instrumenta). Nadalje navode kako se metode prikupljanja podataka (otvorene i zatvorene) stavljaju u određenu kategoriju zbog najčešćeg načina na koji se podaci koriste (brojevi se kvantificiraju, a riječi grupiraju u kodove), a ne i na temelju njihove potencijalne primjene (primjerice, kodirane riječi također se mogu kvantificirati, a brojevi se ne moraju kvantificirati). Stoga su i drugi istraživači (primjerice, Tashakorri i Teddlie, 2003.) naglašavali važnost promišljanja o kontinuumu metodoloških pristupa nasuprot umjetnoj podijeli na dva pristupa, tim više što je kod oba pristupa ključno ulagati napore u izbjegavanju subjektivnosti i osiguravanju vjerodostojnosti i dosljednosti podataka. Bez obzira poimaju li se kvantitativni i kvalitativni pristup kao dio kontinuuma ili binarno, jasno je kako svaki od njih ima svoje prednosti i nedostatke.

$\mathrm{U}$ pokušajima da se iskoriste prednosti te neutraliziraju nedostaci ovih pristupa, istraživači sve češće kombiniraju, odnosno miješaju navedene pristupe u istraživanjima (primjerice, Bryman, 2007.; Mason, 2006., prema Este, Sitter i Maclaurin, 2009.; Burke Johnson, Onwuegbuzie i Turner, 2007.). Pri tome se koristi vjerodostojnost i dosljednost podataka, mogućnost generaliziranja rezultata kvantitativnih metoda, kao i vjerodostojnost i autentičnost kvalitativnih metoda. Drugi dobici mješovitog pristupa uključuju mogućnost obuhvatnijeg odgovaranja na istraživačka pitanja (istraživači mogu podatke koje su dobili jednom metodom upotrijebiti kako bi informirali o podacima dobivenim drugom metodom i na taj način doći do bogatijih i kompletnijih saznanja) te mnogo »jače« dokaze, odnosno one koji su potvrđeni objema metodama (Este, Sitter i Maclaurin, 2009.). lako se čini jasnim kako je mješoviti pristup »dobro« rješenje istraživačkih problema, u literaturi i istraživačkoj praksi česte su rasprave vezane uz to može li se i na koji način miješati kvantitativni i kvalitativni pristup.

U skladu s tim, prisutno je različito razumijevanje, odnosno definiranje mješovitog pristupa istraživanja. Burke Johnson, Onwuegbuzie i Turner (2007.) napravili su pregled definicija mješovitog pristupa od strane nekih relevantnih autora na ovom području te utvrdili kako se te definicije nalaze na kontinuumu, od onih koje ističu da mješoviti pristup obuhvaća prikupljanje kvalitativnih i kvantitativnih podataka, preko onih koji mješoviti pristup definiraju kao onaj koji potencijalno uklju- 
čuje miješanje na svim razinama, do onih koji u svojoj definiciji uključuju miješanje metodoloških pogleda na svijet i jezika.

Dakle, ne postoji slaganje oko toga što i kako se u mješovitom pristupu miješa. Neki autori naglašavaju da se miješaju metode, dok drugi tvrde kako se miješaju različite metodologije. Metodologija je filozofska osnova istraživanja (McGregor i Murnane, 2010.) koja je usko vezana uz određenu paradigmu (Mackenzie i Knipe, 2006.). Kako je kasnije detaljnije objašnjeno, paradigma je pogled na svijet koji predstavlja zajednička vjerovanja istraživačke zajednice i navodi na načine na koje će se istraživački problemi rješavati. (Schwandt, 2001.). S obzirom da su metodologija i paradigma usko vezane i da obje predstavljaju filozofsku osnovu istraživanja, one se u literaturi često poistovjećuju ${ }^{7}$. Za razliku od metodologije, koja se veže uz određen pogled na svijet (paradigmu) i filozofiju (McGregor i Murnane, 2010.), metode su puno konkretnije i praktičnije - one su alat za rad, odnosno za prikupljanje i analiziranje podataka (Giddings i Grant, 2007.; Creswell, 2009.).

U literaturi engleskog govornog područja za mješoviti pristup najčešće se upotrebljava pojam mixed methods, što bi u doslovnom prijevodu značilo miješane metode. lako sam termin implicira kako se u mješovitom pristupu miješaju metode, Freshwater i Cahill (2013.) navode kako taj termin ima dualno značenje te da se rabi kako bi se opisao i a) set procedura i b) metodološki pristup.

Creswell i Plano Clark (2007.: 5) naglašavaju kako se na mješoviti pristup može gledati i kao na miješanje metoda, ali i metodologija te su ponudili sljedeću definiciju mješovitog pristupa: »|straživanje mješovitog pristupa je tip istraživanja koje ima svoje filozofske postavke i metode istraživanja. Kao metodologija, ono uključuje filozofske postavke koje određuju način prikupljanja, analize i miješanje kvalitativnog i kvantitativnog pristupa u mnogim fazama istraživačkog procesa. Kao metoda, ovaj tip istraživanja, usmjeren je na prikupljanje, analiziranje i miješanje kvantitativnih $\mathbf{i}$ kvalitativnih podataka u pojedinom istraživanju ili seriji istraživanja.«.

\section{VRSTE MJEŠOVITOG ISTRAŽIVAČKOG PRISTUPA}

Nekoliko je mogućih vrsta nacrta mješovitog istraživačkog pristupa, a razlikuju se ovisno o tome: 1) kojem metodološkom pristupu (kvantitativnom/kvalitativnom) daju prioritet; 2 ) implementaciji, odnosno redoslijedu kojim slijede pristupi; i 3) fazi u kojoj se podaci integriraju (Morgan 2007.; Creswell, 2009.). S obzirom na prioritet koji se daje jednom tipu istraživanja, mješoviti pristup može se odno-

\footnotetext{
${ }^{7}$ lako bi se zasigurno moglo raspravljati o razlikama između metodologije i paradigme, za potrebe ovog rada dovoljno je naglasiti njihove sličnosti te pretpostaviti da se, kad god se miješaju paradigme, zapravo miješaju i metodologije.
}

\section{2 članci}


siti na nacrt s jednakim statusom (uloga kvalitativnog i kvantitativnog pristupa $\mathrm{u}$ istraživanju je jednako važna) i na nacrt s različitim statusom (istraživanje je dominantno kvalitativno ili kvantitativno, a drugi pristup ga samo nadopunjuje). S obzirom na implementaciju, odnosno vrijeme provođenja kvantitativnog i kvalitativnog dijela, mješovita istraživanja mogu biti sekvencijalna (istraživanje se prvo provede uz pomoć jednog pristupa, a potom drugog) i paralelna/simultana (kvalitativno i kvantitativno istraživanje provode se u isto vrijeme). Integracija kvantitativnih i kvalitativnih podataka može se pojaviti u svim fazama istraživanja, odnosno kod prezentiranja istraživačkih pitanja (zajedno se prezentiraju i kvantitativna i kvalitativna pitanja), kod prikupljanja podataka (primjerice, otvorena pitanja u nekom instrumentu), tijekom analiziranja podataka (primjerice, transformacija kvalitativnih podataka u kvantitativne čestice/skale) te tijekom interpretacije podataka (kvalitativno i kvantitativno istraživanje provodi se odvojeno, a rezultati se uspoređuju i nadopunjuju) (Tashakkori i Teddlie, 2003.).

Kombinacijom navedenih obilježja, Creswell i Plano Clark (2007.) predložili su sljedeće četiri vrste klasifikacije mješovitog nacrta (iako postoje i brojne druge podjele):

1) Konvergentno paralelni nacrt je vrsta istraživanja u kojem oba pristupa (kvantitativni i kvalitativni) imaju jednaku važnost te se odvijaju u isto vrijeme, neovisno jedno o drugome. Pristupi se miješaju u vrijeme interpretacije podataka. Ovaj tip nacrta koristan je za validaciju podataka (prilikom usporedbe rezultata jednog i drugog pristupa) te ilustriranje kvantitativnih rezultata kvalitativnim opisima, odnosno za sveobuhvatnije razumijevanje pojave koja se istražuje.

2) Eksplanatorni sekvencijalni nacrt podrazumijeva prikupljanje podataka prvo kvantitativnim, a potom kvalitativnim metodama. Ovaj pristup može se koristiti kako bi se uz pomoć kvalitativnih podataka razumjeli kvantitativni. Također, kvantitativni podaci mogu služiti za odabir uzorka za kvalitativno istraživanje, a prema određenom kriteriju.

3) Eksplorativni sekvencijalni nacrt uključuje upotrebu kvalitativnog, a potom kvantitativnog istraživačkog pristupa. Upotrebljava se kako bi istraživač, provodeći drugo, kvantitativno istraživanje, generalizirao rezultate kvalitativnog istraživanja. Ovaj pristup često se koristi prilikom razvijanja i testiranja mjernih instrumenata. Jednako tako, ovaj tip nacrta može pomoći u rasvjetljavanju neke nepoznate pojave, kao i u kvantificiranju njenih varijabli.

4) Ugrađeni mješoviti nacrt je vrsta nacrta u kojem se istraživanje temelji na jednom od tradicionalnih pristupa (kvantitativnom ili kvalitativnom), a drugi pristup je ugrađen unutar dominantnog pristupa (Plano Clark i sur., 2008.). Svrha prikupljanja kvantitativnih i kvalitativnih podataka nije u njihovom uspoređivanju, već $u$ adresiranju različitih aspekata istraživanja. Ovaj nacrt prikladan je stoga u 
slučajevima u kojima istraživač ima različita istraživačka pitanja koja zahtijevaju različite vrste podataka. Primjerice, tijekom eksperimenta, istraživač može provesti intervju sa sudionicima istraživanja kako bi stekao uvid u reakcije sudionika na eksperiment, kako bi istražio proces ili intervenciju, ili kako bi unaprijedio postupak odabira sudionika (Creswell i Plano Clark, 2011.). Također, istraživač može upotrijebiti standardizirani upitnik kako bi u sklopu studije slučaja procijenio određena obilježja neke osobe i usporedio ih s rezultatima populacije. Ugrađeni mješoviti nacrt posebno je koristan u situaciji u kojoj istraživač nema vremena provesti opširno istraživanje metodologijom koja je u ugrađenom nacrtu nedominantna.

\section{ISTRAŽIVAČKE PARADIGME U DRUŠTVENIM ZNANOSTIMA}

U podlozi gore opisanih rasprava vezanih uz definiranje mješovitog istraživačkog pristupa kao i uz njegovo razvrstavanje u četiri podvrste jest pitanje uključuju li metode prikupljanja i analiziranja podataka nužno određene teorijske postavke i vrijednosti (metodologiju). Ukoliko uključuju, je li moguće miješati metodologiju i na koji način? Teorijske postavke i vrijednosti znanstvenog istraživanja, odnosno metodologija istraživanja pripadaju određenoj paradigmi (Creswell i Plano Clark, 2007.). Paradigma u kontekstu znanstvenih istraživanja ima barem četiri značenja: 1) pogled na svijet, 2) epistemološki stav, 3) zajednička vjerovanja istraživačke zajednice, 4) model primjer istraživanja (Morgan, 2007.). Najčešće upotrebljavano shvaćanje paradigme jest da je riječ o epistemološkom stavu, odnosno da se paradigme razlikuju vezano uz njihov stav o prirodi znanja i onoga koji saznaje. Ovaj pristup imao je snažan utjecaj na rasprave oko toga je li moguće miješati kvantitativne i kvantitativne metode (Morgan, 2007.). Uz epistemologiju (stav o odnosu znanja i onog koji saznaje), svaka paradigma ima i svoju jedinstvenu ontologiju (stav o prirodi stvarnosti) i aksiologiju (stav o ulozi vrijednosti u istraživanju). Koristeći te dimenzije, Teddlie i Tashakkori (2009.) identificirali su pet osnovnih paradigmi: pozitivizam, postpozitivizam, konstruktivizam, transformativnu paradigmu i pragmatizam. lako se u literaturi spominju i druge paradigme, ovaj rad fokusirat će se na navedenih pet paradigmi, koje su detaljnije objašnjene u Tablici 1. i tekstu koji slijedi.

\section{4 članci}




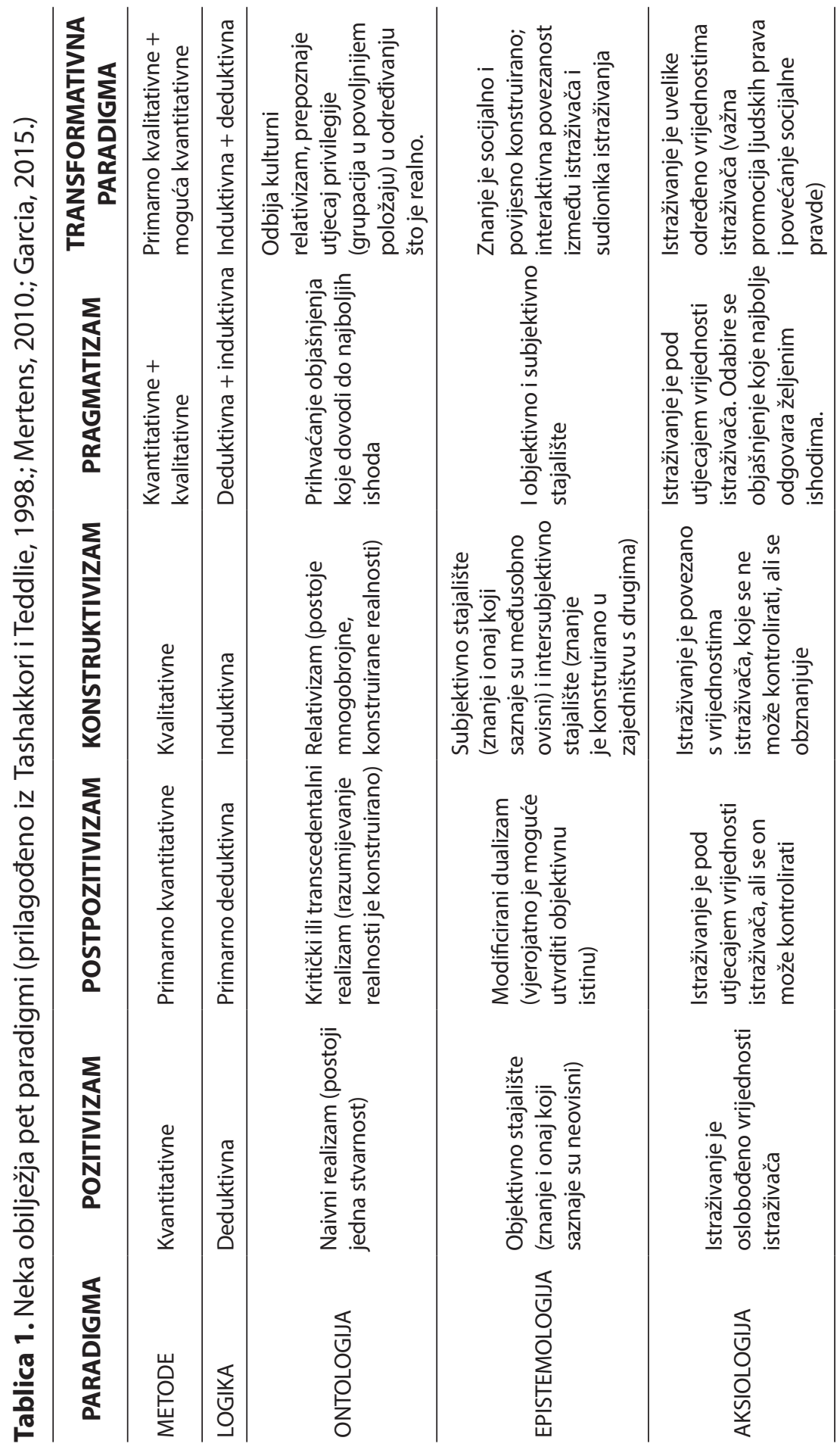


Prema pozitivističkoj paradigmi, postoji jedna realnost koju je moguće objektivno utvrditi i mjeriti (Guba i Lincoln, 1994.). Istraživač je objektivan i odvojen od ispitanika istraživanja kako bi se uklonila istraživačka pristranost (Burke Johnson i Onwuegbuzie, 2004.).

Postpozitivistička paradigma nastala je na temelju prepoznavanja ideoloških i praktičnih ograničenja pozitivizma. Za razliku od pozitivista koji pretpostavljaju linearne uzročno-posljedične veze, postpozitivisti ishod percipiraju kao rezultat kompleksnog utjecaja mnogobrojnih uzročnih čimbenika koji su u interakciji. Postpozitivisti smatraju kako je realnost socijalno i kulturalno konstruirana te da je objektivnost nemoguća. U skladu s tim, govore o rezultatima koji »podržavaju«, a ne »potvrđuju« hipoteze (Tashakkori i Teddlie, 1998.). lako se većina kvantitativnih istraživanja temelji na ovoj paradigmi, ona je vrlo utjecajna i u mješovitom pristupu, posebice onome dominantno kvantitativnome (Giddings i Grant, 2007.). Zbog postpozitivističkih nastojanja kvantificiranja pojava, neki autori smatraju da je postpozitivizam toliko sličan pozitivizmu da je upitno je li riječ o zasebnoj paradigmi (Guba i Lincoln, 2005.).

Konstruktivistička paradigma temelji se na pretpostavci kako ne postoji jedna objektivna stvarnost, već postoje višestruke stvarnosti koje su uvelike ovisne o pojedincu, vremenu i kontekstu (Guba i Lincoln, 2005.). Odnosno, pojedinci kroz interakciju i u zajedništvu s drugima te kroz socijalne i kulturne norme razvijaju subjektivna značenja svojih iskustava (intersubjektivnost) (Creswell, 2014.). Svrha konstruktivizma je razumjeti kontekstualizirana značenja i smislenost ljudskih akcija i interakcija stoga konstruktivizam zagovara istraživanje smisla koji ljudi daju određenim situacijama u određenom vremenu (Bisman i Highfield, 2012.). U istraživanju koje je temeljeno na ovoj paradigmi nastoji se istražiti perspektiva sudionika, pri čemu se pažnja usmjerava i na procese interakcije pojedinca s drugima. Unutar konstruktivističke paradigme, istraživač i sudionici istraživanja povezani su $\mathrm{u}$ istraživačkom procesu, a rezultati su kreirani kroz njihovu interakciju; vrijednosti istraživača uvelike utječu na istraživanje i to se »priznaje« u istraživanju (Creswell, 2014.). Za razliku od postpozitivizma, koji smatra kako postoje cirkularne uzročne veze, prema konstruktivizmu uzročne veze su nesustavne, nehijerarhijske, kaotične, kompleksne i kontekstualne (Tashakoori i Teddlie, 1998.).

Pragmatizam je nastao kao pokušaj »mirenja« suprotnih paradigmi. Njime se nastoji dekonstruirati mišljenje prema kojemu su određeni koncepti »istina« i »realnost«, što dovodi do nerješivih pseudoproblema. Pragmatičari potiču eklekticizam i pluralizam te odbacuju prisilni izbor između pozitivizma i konstruktivizma jer smatraju kako istraživači mogu biti i objektivni i subjektivni u epistemološkoj orijentaciji (Burke Johnson i Onwuegbuzie, 2004.). Prema de Waalu (2005.), logika pragmatizma je upotreba indukcije (otkrivanje obrazaca), dedukcije (testiranje teorija

\section{6 članci}


i hipoteza) i abdukcije (otkrivanje najboljeg seta objašnjenja rezultata). Pragmatičari naglašavaju kako je istraživačko pitanje važnije i od metode koja se upotrebljava i od pogleda na svijet. Dobri istraživači preferiraju odgovaranje na istraživačko pitanje s dostupnom, prikladnom metodom (Burke Johnson i Onwuegbuzie, 2004.). Pragmatizam je privlačan jer: a) daje paradigmu koja filozofski obuhvaća korištenje mješovitog pristupa; b) izbjegava korištenje metafizičkih koncepata; i c) predstavlja vrlo praktičnu i primjenjivu filozofiju istraživanja (Tashakkori i Teddlie, 1998).

No, ovaj pristup je i kritiziran, najviše od strane europskih filozofa koji naglašavaju da je pragmatizam usmjeren uspjehu istraživanja, a ne istini. Hall (2012.) naglašava kako pragmatizam ne može ponuditi koherentnu racionalu za upotrebu mješovitog pristupa zbog nedostatka jasne definicije oko toga što daje »dobre« rezultate istraživanja, dok Giddings i Grant (2007.) smatraju kako je pragmatizam ideološka pozicija koja može biti dostupna unutar bilo koje paradigme.

Transformativna paradigma naglašava kako stvarnost definiraju privilegirane društvene skupine koje imaju moć. Upravo ovo obilježje odvaja ju od konstruktivizma koji smatra kako je stvarnost definirana u zajedničkoj interakciji subjekata, no ne navodi pitanja moći određenih skupina. Transformativna paradigma ističe važnost socijalne pravde i osnaživanja marginaliziranih glasova putem istraživanja (Mertens, 2010.). Kritika transformativne paradigme odnosi se na činjenicu da je ona često ograničena na samo manji dio društvenih zbivanja (Hall, 2012.) i da su njene postavke toliko specifične da više predstavljaju svrhu nekog istraživanja (Tashakkori i Teddlie, 2003.) nego zasebnu paradigmu.

Od opisanih pet paradigmi, pozitivizam i postpozitivizam najčešće su povezani s kvantitativnim istraživanjima, a konstruktivizam s kvalitativnim. Transformativna paradigma i pragmatizam najčešće se vežu uz mješoviti pristup. Ipak, unatoč opisanim razlikama navedenih paradigmi, neki autori (npr. Morgan, 2007.) smatraju da su granice između paradigmi još uvijek nejasne i više određene interesima istraživača nego istinskim filozofskim razlikama. Rasprave o granicama paradigmi i pridruživanju im različitih istraživačkih pristupa (kvalitativnih, kvantitativnih ili mješovitih) stoga još uvijek traju.

\section{MOGUĆNOSTI MIJEŠANJA KVANTITATIVNOG I KVALITATIVNOG PRISTUPA S OBZIROM NA VRSTU MJEŠOVITOG PRISTUPA: MIJEŠANJE METODA ILI METODOLOGIJA?}

Različita su stajališta vezana uz to je li i na koji način moguće miješati kvantitativni i kvalitativni pristup, posebice uzmu li se u obzir različite paradigme vezane 
uz njih. Debate na ovu temu, izrazito aktualne 70-ih i 80-ih godina prošlog stoljeća, i dalje traju. Pri tome, neki autori smatraju kako miješanje kvalitativnih i kvantitativnih metoda u jednom istraživanju nije moguće zbog različitosti paradigmi koje su u podlozi navedenih pristupa pri čemu prihvaćanje jedne paradigme za sobom povlači isključivanje druge (Guba i Lincoln, 1994.). Denzin i Lincoln (1994.), primjerice, upozoravaju da različite paradigme istraživača navode na različite stilove istraživanja, različite epistemologije te različite oblike predstavljanja istraživanja. Stoga Holmes (2006., prema Denzin i Lincoln, 2011.) smatra kako je nemoguće u jednom dijelu istraživanja zastupati jedan pogled na svijet, a u drugom suprotni. U osnovi ovakvih stajališta je pretpostavka da su metode nužno povezane s paradigmama i da stoga istraživač, kada miješa metode, miješa i paradigme, što je prema navedenim autorima nemoguće.

Druga, brojnija skupina autora smatra kako je kombiniranje kvalitativnog i kvantitativnog pristupa u jednom istraživanju ipak moguće, pri čemu zastupaju tri moguća pristupa. Prvi pristup poznat je kao aparadigmatizam, drugi kao pristup višestrukih paradigmi, a treći kao pristup jedinstvenih paradigmi. U tekstu koji slijedi, svaki od navedenih pristupa bit će kratko objašnjen, a zatim raspravljen u kontekstu: a) vrste mješovitog istraživanja u kojem se najčešće javlja i b) miješanja metoda ili metodologija.

\section{Aparadigmatizam}

Autori koji pribjegavaju aparadigmatičnosti ignoriraju pitanja paradigme jer tvrde kako je upotreba metoda neovisna od epistemologije (Patton, 1990., prema Apolo Peter, 2010.), odnosno kako prihvaćanje jedne paradigme ne znači nužno upotrebu metoda koje se obično upotrebljavaju s tom paradigmom. Kritičari ovog stajališta (primjerice, Apolo Peter, 2010.) tvrde kako su epistemologija i metodologija povezane jer epistemološka pozicija implicira ograničenja vezana uz vrstu podataka koji se prikupljaju te načine na koji se podaci analiziraju. Kao primjer navode nelogičnosti toga da konstruktivist analizira podatke primjenjujući multiplu regresiju.

Međutim, kritičari ovog pristupa ne uzimaju u obzir istinsku razliku između metoda prikupljanja podataka i metoda obrade podataka. Logično je da konstruktivist neće analizirati kvalitativne podatke primjenjujući multiplu regresiju, niti će pozitivist analizirati kvantitativne podatke cikličkim kodiranjem karakterističnim za utemeljenu teoriju, primjerice. To ne znači, međutim, da do miješanja ne može doći na drugim razinama. Dok se metode analize podataka gotovo isključivo vežu uz određenu paradigmu, metode prikupljanja kvantitativnih i kvalitativnih podataka mogu se vezati uz različite paradigme. Pozitivist tako može koristiti dubinske inter-

\section{8 članci}


vjue za bolje razumijevanje rezultata multiple regresije. $U$ tom slučaju radilo bi se o klasičnom sekvencijalnom eksplanatornom istraživanju u kojem se kvalitativna metodologija koristi kao dodatak kvantitativnoj, s ciljem pomoći u interpretaciji rezultata primarno kvantitativnog istraživanja. Drugim riječima, u tom slučaju radilo bi se o primarno pozitivističkom istraživanju s kvalitativnim dodatkom.

Slično, konstruktivist može biti zabrinut oko iskrenosti odgovora koje je dobio intervjuirajući sudionike o nekoj osjetljivoj temi te stoga može nakon provedenih intervjua s istim ispitanicima primijeniti anonimne upitnike kako bi utvrdio razlikuju li se podaci prikupljeni intervjuima od podataka prikupljenih anonimnim upitnicima. Ukoliko je istraživač u takvom istraživanju prije svega usmjeren na dubinsko razumijevanje procesa koji se nalaze u pozadini odgovora sudionika istraživanja, riječ je o klasičnom sekvencijalnom eksploratornom nacrtu u kojem je dominantna kvalitativna metodologija pri čemu se kvantitativna samo koristi kao njen dodatak s ciljem validacije kvalitativnih rezultata. $U$ oba slučaja, rezultati se integriraju u fazi njihove interpretacije pri čemu se kvalitativni i kvantitativni rezultati uspoređuju i nadopunjuju.

Uz sekvencijalni nacrt, aparadigmatični pristup karakterističan je i za ugrađeni mješoviti pristup u kojem, kao i u sekvencijalnom nacrtu, postoji jedna »dominantna paradigma i za nju relevantna metoda u koju se onda »ugrađuje« metoda suprotna metodi dominantne paradigme pri čemu se podaci integriraju na razini njihovog analiziranja.

Konačno, činjenica da autori koji zagovaraju aparadigmatičnost polaze od pretpostavke da prihvaćanje jedne paradigme ne znači nužno upotrebu metoda koje se obično primjenjuju s tom paradigmom, zapravo znači da se kod aparadigmatičnog pristupa ne radi o »ignoriranju« ili »napuštanju« paradigmi. Naprotiv, radi se o tome da se $u$ istraživanju polazi od jedne »dominantne« paradigme, ali da se unutar nje mogu koristiti metode koje za tu paradigmu inače nisu uobičajene. Pogrešno bi, stoga, bilo aparadigmatičnost svrstavati u potpuno napuštanje ili ignoriranje paradigmi. Točnije bi bilo aparadigmatični pristup vidjeti kao pristup koji ne pridaje prevelik značaj raspravama o paradigmama, već vrlo pragmatično dozvoljava miješanje kvalitativnih i kvantitativnih metoda u okviru jedne dominantne paradigme, bilo kvalitativne ili kvantitativne. Aparadigmatični pristup stoga je pristup u kojem se miješaju metode, ne metodologije, odnosno paradigme. Aparadigmatična istraživanja polaze od jedne »dominantne« paradigme čiji značaj pretjerano ne ističu. 


\section{Višestruki paradigmatizam}

Višestruki paradigmatizam naglašava kako istraživači, u podlozi svojeg istraživanja, mogu imati više od jedne paradigme. Tashakkori i Teddlie (2003.) identificirali su tri moguća oblika ovog pristupa: teze o komplementarnim snagama, dijalektičke teze i teze o različitim paradigmama primjenjivim specifičnom nacrtu mješovitog pristupa.

Autori koji podržavaju teze o komplementarnim snagama (primjerice, Brewer i Hunter, 1989.; Morse, 2003.) smatraju kako tradicionalne paradigme nisu fundamentalno inkompatibilne, već su različite u važnim elementima. Te su razlike vrijedne i trebaju biti očuvane kako bi se održao metodološki integritet. Pri tome je važno metode koje se koriste unutar različitih paradigmi držati odvojenima kako bi se očuvala valjanost obje metode (Brewer i Hunter, 1989.).

S obzirom da pristup tezi o komplementarnim snagama zahtijeva odvajanje metoda pojedinih paradigmi, ovaj pristup odgovarajući je za konvergentno paralelni mješoviti nacrt u kojem se u jednoj vremenskoj točki prikupljaju obje vrste podataka koje se potom analiziraju odvojeno u sklopu paradigmi karakterističnih za primjenu određene metode. Za razliku od sekvencijalnog aparadigmatskog nacrta, u kojemu postoji jedna »dominantna« paradigma unutar koje se miješaju kvalitativne i kvantitativne metode, pristup komplementarnih snaga jednaku važnost daje kvalitativnom i kvantitativnom dijelu istraživanja, a time i paradigmama karakterističnim za te pristupe. Kao i u sekvencijalnom nacrtu, u pristupu komplementarnih snaga istraživač zapravo provodi dva odvojena (ali u ovom slučaju paralelna) istraživanja, zasebno analizira podatke te ih integrira u fazi interpretacije. Za razliku od sekvencijalnog nacrta, u kojem u fazi interpretacije kvalitativni podaci služe za pojašnjavanje kvantitativnih podataka (ili obrnuto), a u okviru jedne dominantne paradigme od koje se je $\mathrm{u}$ istraživanje krenulo, u pristupu komplementarnih snaga u fazi interpretacije jednaka se važnost daje kvalitativnim i kvantitativnim podacima i pripadajućim im paradigmama. Nema »dominantne« paradigme, niti kvalitativni podaci služe za objašnjenje kvalitativnih ili obrnuto. U istraživanje se kreće s dvije različite paradigme koje se onda povezuju nakon analize podataka u fazi njihove interpretacije. U pristupu komplementarnih snaga radi se, stoga, o miješanju metoda, ali i metodologija, odnosno paradigmi ${ }^{8}$.

\footnotetext{
${ }^{8}$ S obzirom da miješanje metodologija, odnosno paradigmi uvijek znači i miješanje metoda, od ove točke na dalje ovaj rad pod miješanjem metodologija automatski podrazumijeva i miješanje metoda. Stoga, kad pričamo o vrstama mješovitog pristupa i pripadajućim im pristupima koji se temelje na miješanju metoda, mislimo na vrste mješovitih istraživanja koje miješaju samo metode, ne metodologije. S druge strane, kad pričamo o miješanju metodologija, podrazumijevamo da ono uključuje i miješanje metoda.
}

\section{0 članci}


Ovo povezivanje i metoda i metodologija komplicirano je i zahtijeva izuzetnu metodološku vještinu kojom istraživač mora u jednom istraživanju integrirati i jednaku važnost pridati dvama različitim pogledima na svijet. S obzirom da je uistinu teško na prikladan način krenuti od pretpostavke da je svijet oko nas moguće objektivno mjeriti i pri tome istovremeno pretpostavljati da nema jedne objektivne realnosti, nego samo značenja koju joj ljudi pridaju, pristup komplementarnih snaga, odnosno konvergentno paralelni mješoviti pristup je u mješovitim istraživanjima vrlo rijedak.

Prema pristupu dijalektičkih teza, miješanja »mentalnih modela«, odnosno seta pretpostavki, razumijevanja, predispozicija, vrijednosti i vjerovanja koja su u podlozi svakog istraživanja su dobra jer mogu dovesti do novih spoznaja (Greene i Caracelli, 1997.; Maxwell i Loomis, 2003., prema Greene, 2008.). Greene (2007.: 79) elaborira ovo shvaćanje izjavom da je pristup dijalektičkih teza: »Razumijevanje koje je isprepleteno s jedinstvenosti i općenitosti, kontekstualnom kompleksnosti i regularnosti, unutarnjom i vanjskom perspektivom, promjenom i stabilnosti. (...) Ono ne traži toliko konvergenciju kao što traži uvid. (...) U dobrom istraživanju mješovitog tipa razlike su konstitutivne i generativne«. Betzner (2008.) navodi kako je ispreplitanje paradigmi izrazito zahtjevno jer istraživač treba promisliti kako je određena paradigma utjecala na rezultate određene metode, a potom u kakvoj su interakciji rezultati i postavke jedne paradigme s rezultatima i postavkama druge ili treće paradigme. Giddings i Grandt (2007.) slažu se s tim te navode nekoliko primjera u kojima su autori, uz takvu ambiciju, članak završili s tvrdnjom kako u tome nisu uspjeli. Pristup dijalektičkih teza stoga je izuzetno sličan pristupu komplementarnih snaga i za njega karakterističnom konvergentno paralelnom mješovitom pristupu te je kao takav vrlo zahtjevan i rijedak.

Prema tezama o različitim paradigmama primjenjivim specifičnom nacrtu mješovitog pristupa, svaki nacrt mješovitog pristupa ima upotrebljivu paradigmu te istraživač treba odlučiti koja paradigma je relevantna za određeni nacrt. Dakle, prema ovim tezama, neke paradigme su prikladne za jednu vrstu nacrta, no ne i za drugu. Creswell i Plano Clark (2007.) navode kako prema ovoj perspektivi, istraživači mogu vidjeti mješoviti pristup isključivo kao metodu, što im dopušta da upotrijebe bilo koju filozofsku podlogu. S obzirom da i sami autori navode da se u ovom pristupu zapravo ne radi o miješanju paradigmi, odnosno metodologija, već samo o miješanju metoda unutar jedne »dominantne« paradigme relevantne za određeni nacrt, nelogično je da se teze različitih paradigmi svrstavaju u višestruki paradigmatizam. Radi se o pristupu koji se ni po čemu ne razlikuje od aparadigmatizma i za njega karakterističnih sekvencijalnih i ugrađeno-mješovitih nacrta. 


\section{Pristup jedinstvenih paradigmi}

Autori koji zastupaju pristup jedinstvenih paradigmi (primjerice, Burke Johnson i Onwuegbuzie, 2004.; Mertens, 2010.; Teddlie i Tashakkori, 1998.) naglašavaju kako se povijesne filozofske različitosti između paradigmi mogu prevladati uz pomoć novih paradigmi, poput pragmatizma i transformativnog pristupa opisanih ranije. Pitanje je, međutim, možemo li navedene dvije "paradigme« smatrati zasebnim paradigmama, odnosno paradigmama koje su kvalitativno drugačije od ostalih paradigmi. S obzirom da je transformativna paradigma toliko uska da više nalikuje na istraživačko pitanje nego na pogled na svijet koji bi na bilo koji način bio kvalitativno drugačiji od ostalih paradigmi, ne samo da ne može imati obilježja zasebne paradigme, nego ne dozvoljava ni raspravu o tome veže li se uz nju miješanje metoda ili metodologija. Ona se naprosto odnosi na istraživačko pitanje na koje istraživač može pokušati odgovoriti bilo u okviru aparadigmatizma ili višestrukog paradigmatizma koristeći se za njih relevantnim mješovitim pristupima, naravno ukoliko se na navedeno istraživačko pitanje u konkretnom slučaju odgovara mješovitim pristupom.

Razumijevanje pragmatizma kao zasebne "paradigme« je dvojako. $S$ jedne strane, pragmatizam se odnosi na istovremeno miješanje i naizgled suprotstavljenih pogleda na svijet (primjerice, pozitivističkog i konstruktivističkog) i pripadajućih im metoda (tzv. teorijski pragmatizam), a s druge strane odnosi se samo na miješanje metoda kojima će se najlakše odgovoriti na istraživačko pitanje (tzv. metodološki pragmatizam). U slučaju teorijskog pragmatizma radi se, međutim, o miješanju već postojećih paradigmi koje se ni po čemu ne razlikuje od višestrukog paradigmatizma opisanog ranije. Drugim riječima, u kontekstu miješanja paradigmi, pragmatizam ne nudi ništa kvalitativno drugačije od višestruko paradigmatičnih pristupa komplementarnih snaga i dijalektičkih teza za koje je karakterističan konvergentno paralelni mješoviti pristup. Ne govori nam ništa novo o tome kakva je pragmatizam točno paradigma, odnosno od kakvog pogleda na svijet polazi, a koji bi bio različit od već postojećih. Govori nam samo o tome da je to paradigma koja dozvoljava miješanje metodologija, odnosno drugih paradigmi. To miješanje paradigmi, međutim, može biti toliko različito i može poprimiti velik broj oblika, da je uistinu teško govoriti o zasebnoj paradigmi.

U kontekstu metodološkog pragmatizma, zapravo je riječ o bilo kojem od ranije opisanih načina miješanja kvalitativnog i kvantitativnog pristupa u kojem se miješaju samo metode, a ne metodologije, uključujući sekvencijalni i ugrađeni mješoviti pristup. S obzirom da se u ovakvom pragmatizmu miješaju samo metode, a ne paradigme, u ovom slučaju tek ne možemo govoriti o pragmatizmu kao o zasebnoj paradigmi. Naprotiv, u ovom slučaju možemo govoriti samo o tezi razli-

\section{2 članci}


čitih paradigmi ili aparadigmatizmu za koje su karakteristični sekvencijalni i ugrađeni mješoviti nacrti.

\section{RASPRAVA: PRIJEDLOG JEDNOSTAVNIJE PODJELE RAZLIČITIH MOGUĆNOSTI MJEŠOVITOG PRISTUPA}

U prethodnoj cjelini ovog rada prikazano je da: a) iako termin to implicira, aparadigmatičnost ne znači napuštanje ili ignoriranje paradigmi; b) se teze o različitim paradigmama, iako u literaturi originalno svrstane u višestruki paradigmatizam za koji je karakteristično miješanje metodologija, ne razlikuju značajno od aparadigmatizma te da se odnose samo na miješanje metoda, ne metodologija; c) se pragmatizam može odnositi i na miješanje metoda i na miješanje metodologija te da ga je teško smatrati zasebnom paradigmom koja bi bila kvalitativno drugačija od ostalih paradigmi; i d) je transformativna paradigma toliko uska da više nalikuje na istraživačko pitanje, bez da nudi kvalitativno drugačiji pogled na svijet od već postojećih paradigmi te da kao takva nije zasebna paradigma i da je stoga neprikladna za rasprave o tome miješaju li se unutar nje metode ili metodologije.

U radu je prikazano i da se od svih raspravljenih mogućnosti mješovitog pristupa u najvećem broju slučajeva radi o miješanju metoda, ne metodologija. Točnije, o miješanju metoda radi se u sljedećih devet prethodno raspravljenih situacija: 1) sekvencijalnom eksplanatornom aparadigmatičnom nacrtu; 2) sekvencijalno eksploratornom aparadigmatičnom nacrtu; 3) ugrađenom mješovitom aparadigmatičnom nacrtu; 4) sekvencijalnom eksplanatornom nacrtu temeljenom na tezama o različitim paradigmama; 5) sekvencijalno eksploratornom nacrtu temeljenom na tezama o različitim paradigmama; 6) ugrađenom mješovitom nacrtu temeljenom na tezama o različitim paradigmama; 7) sekvencijalnom eksplanatornom nacrtu temeljenom na metodološkom pragmatizmu; 8) sekvencijalnom eksploratornom nacrtu temeljenom na metodološkom pragmatizmu; i 9) ugrađenom mješovitom nacrtu temeljenom na metodološkom pragmatizmu. Miješanje metodologija, kako je raspravljeno u prethodnom poglavlju, znatno je rjeđe, odnosno prisutno u sljedeće tri situacije: 1) konvergentno paralelnom mješovitom nacrtu teza komplementarnih snaga; 2 ) konvergentno paralelnom mješovitom nacrtu pristupa dijalektičkih teza; i 3) konvergentno paralelnom mješovitom nacrtu koji se veže uz teorijski pragmatizam.

Već kratki uvid u prethodna dva odlomka, a posebice detaljniji pregled prethodnog poglavlja ovog rada, ukazuju na činjenicu da među različitim mogućnostima mješovitog pristupa opisanim u metodološkoj literaturi postoje velika preklapanja. Tako se aparadigmatični pristup, pristup teza različitih paradigmi i metodološki pragmatizam svaki ponaosob vežu uz: a) miješanje metoda, ne metodologija i b) sekvencijalni (bilo eksploratorni ili eksplanatorni) i ugrađeni mješoviti nacrt. 
Slično, pristup teza o komplementarnim snagama, pristup dijalektičkih teza i teorijski pragmatizam svaki ponaosob vežu se uz: a) miješanje metodologija i b) konvergentno paralelni mješoviti nacrt.

S obzirom na velika preklapanja raspravljenih mogućnosti miješanja kvalitativnog i kvantitativnog istraživanja, umjesto držanja tih mogućnosti brojnima i odvojenima u pokušaju isticanja često malih razlika među njima, moguće ih je »ukrupniti« u dvije osnovne, jednostavnije skupine - jednu koja se odnosi na miješanje metoda i drugu koja se odnosi na miješanje metodologija (Tablica 2.) ${ }^{9}$. Sve ostale mogućnosti (polazišta) miješanja kvalitativnog i kvantitativnog istraživanja i pripadajuće im vrste mješovitog nacrta mogu se onda svrstati u jednu od te dvije velike skupine. Pri tome je važno naglasiti da je za istraživača koji planira provesti mješovito istraživanje najvažnija odluka o tome koja vrsta mješovitog nacrta istraživanja je najprikladnija za odgovaranje na postavljena istraživačka pitanja. Odabir odgovarajućeg nacrta ujedno je i odgovor na pitanje miješaju li se u tom nacrtu metode ili metodologije. ${ }^{10}$

Tablica 2. Dvije osnovne skupine mogućnosti miješanja kvalitativnih i kvantitativnih istraživanja

\begin{tabular}{|c|c|c|c|}
\hline \multicolumn{2}{|c|}{ I. Miješanje metoda } & \multicolumn{2}{|c|}{ I. Miješanje metodologija } \\
\hline Polazište & $\begin{array}{c}\text { Vrsta mješovitog } \\
\text { pristupa }\end{array}$ & Polazište & $\begin{array}{c}\text { Vrsta mješovitog } \\
\text { pristupa }\end{array}$ \\
\hline 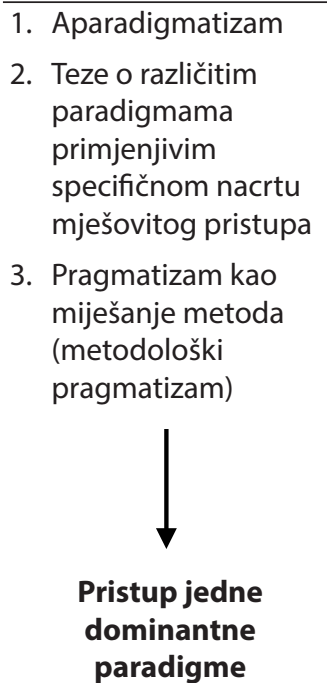 & $\begin{array}{l}\text { 1. Eksplorativno } \\
\text { sekvencijalni nacrt } \\
\text { 2. Eksplanatorno } \\
\text { sekvencijalni nacrt } \\
\text { 3. Ugrađeni mješoviti } \\
\text { nacrt }\end{array}$ & 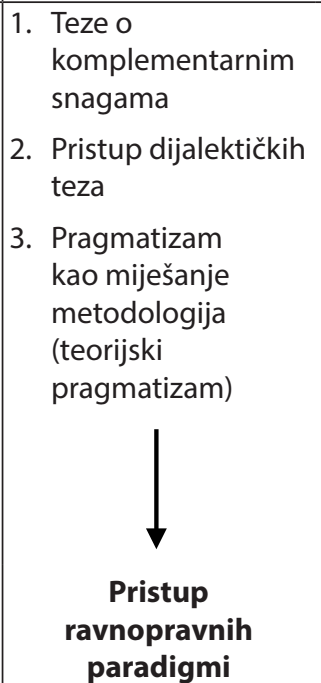 & $\begin{array}{l}\text { 1. Konvergentno } \\
\text { paralelni } \\
\text { mješoviti nacrt }\end{array}$ \\
\hline
\end{tabular}

${ }^{9}$ Kako je ranije naglašeno, miješanje metodologija automatski znači i miješanje metoda, ne samo paradigmi.

${ }^{10} \mathrm{Kao}$ što je detaljnije objašnjeno dolje, sekvencijalni nacrt, primjerice, automatski znači miješanje samo metoda, ne metodologija. 
Polazišta koja se uz odabrani istraživački nacrt vežu manje su važna, tim više što su, unutar jedne od osnovne dvije skupine prikazane u Tablici 2., razlike među njima minimalne. Primjerice, kako je ranije prikazano, razlike između aparadigmatizma, teza o različitim paradigmama i metodološkog pragmatizma toliko su male i u literaturi nedovoljno »razdijeljene« da se njihovo postojanje kao zasebnih pristupa čini neopravdanim. Sličnosti je među navedena tri pristupa puno više nego razlika. Točnije, svaki od navedenih pristupa veže se uz miješanje metoda, ne metodologija, i to uz primjenu sekvencijalnog ili ugrađenog mješovitog pristupa. Također, svaki od navedenih pristupa polazi od jedne »dominantne« paradigme, bilo kvalitativne ili kvantitativne, dok druga, manje dominantna paradigma služi kao dodatak za bolje razumijevanje dominantnog dijela istraživanja. Pri tome, ni jedan od tri pristupa ne nudi ništa kvalitativno drugačije od preostala dva, a što bi opravdalo njegovo klasificiranje kao posebnog pristupa. Slično je i s tezama o komplementarnim snagama, pristupom dijalektičkih teza i teorijskim pragmatizmom budući da se svaki od njih veže uz konvergentno paralelni mješoviti pristup i ravnopravno miješanje metodologija, odnosno paradigmi, bez da nudi bilo što kvalitativno drugačije od preostala dva pristupa. Stoga je umjesto specificiranja različitih polazišta unutar svake od dvije osnovne kategorije mješovitog pristupa, sva polazišta unutar kategorije koja se odnosi na miješanje metoda moguće je nazvati "pristupom jedne dominantne paradigme«, dok je sva polazišta unutar kategorije koja se odnosi na miješanje metodologija moguće nazvati »pristupom ravnopravnih paradigmi« (Tablica 2.).

Slika 1. daje još jednostavniji prikaz Tablice 2. koji može poslužiti kao vodič istraživačima koji planiraju mješovito istraživanje. Kako je naglašeno ranije, za istraživača koji planira provesti mješovito istraživanje najvažnija je odluka o tome koja vrsta mješovitog istraživanja je najprikladnija za odgovaranje na postavljena istraživačka pitanja. Drugim riječima, kako je vidljivo iz slike 1., istraživači u bilo koje istraživanje, pa tako i u ono mješovito, prije svega kreću od svojih istraživačkih pitanja (korak 1). Ovisno o istraživačkim pitanjima/hipotezama, odabire se nacrt istraživanja kojim će se najprikladnije odgovoriti na istraživačka pitanja. U slučaju mješovitog istraživanja, istraživači mogu odabrati jedno od opisane četiri vrste istraživanja - 1. sekvencijalni eksploratorni nacrt; 2 . sekvencijalni eksplanatorni nacrt; 3. ugrađeni mješoviti nacrt ili 4. konvergentno paralelni mješoviti nacrt (korak 2). Odabir odgovarajućeg nacrta vodi istraživače do koraka tri predloženog vodiča, koji i nije »korak« u pravom smislu te riječi nego faza planiranja mješovitog istraživačkog procesa u kojoj leži odgovor na pitanje miješaju li se u tom nacrtu metode ili metodologije.

Pri tome, u vodiču predstavljenom na slici 1. ni na koji način ne zanemaruje se važnost paradigmi. Naprotiv, navodeći radi li se o pristupu jedne dominantne 
paradigme ili pristupu ravnopravnih paradigmi u predloženom vodiču, u koraku tri upravo se naglašava važnost paradigmi u mješovitom istraživanju, pretpostavljajući da, kao i u slučaju ostalih istraživanja, svaki mješoviti pristup počiva na određenoj paradigmi ili paradigmama. Međutim, za razliku od postojeće metodološke literature, u predloženom vodiču suzdržava se od daljnjih rasprava o paradigmama u mješovitom istraživanju. Takve rasprave smatraju se nepotrebnima jer istraživači, prije nego postave istraživačka pitanja, trebaju biti upoznati s osnovnim postavkama svake od tri paradigme uvrštene u Sliku 1. te biti svjesni da njegova istraživačka pitanja $i$ istraživački nacrti za sobom povlače odgovarajuću paradigmu ili paradigme. ${ }^{11}$ Primjerice, želi li istraživač ispitati stavove zagrebačkih srednjoškolaca o državnoj maturi te utvrditi što oblikuje takve stavove, istraživač će se automatski odlučiti za sekvencijalno eksplanatorno istraživanje i pozitivizam kao dominantu paradigmu. Slika 1. stoga omogućava istraživačima planiranje mješovitog istraživanja bez zbunjujućih dodatnih rasprava o paradigmama u kontekstu mješovitih istraživanja.

KORAK 1

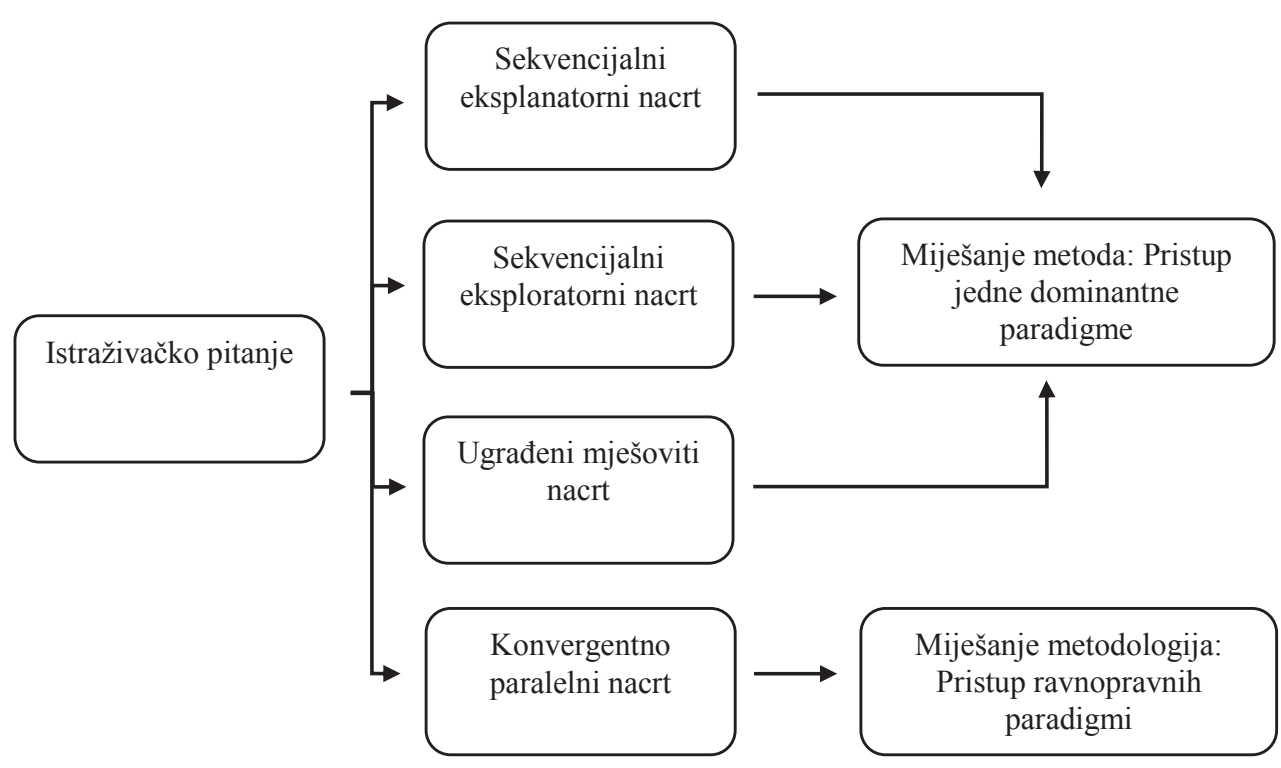

Slika 1. Vodič pri planiranju mješovitog pristupa

${ }^{11}$ Ovdje se referira na tri paradigme (pozitivizam, postpozitivizam i konstruktivizam), a ne na svih pet prethodno opisanih paradigmi jer je ranije utvrđeno kako pragmatizam i transformacijska paradigma nisu zasebne paradigme.

\section{6 članci}




\section{ZAKLJUČAK}

Ovim radom raspravljaju se izazovi mješovitog istraživačkog pristupa te se nude prijedlozi praktičnih rješenja po tom pitanju. Riječ je o prvom radu koji se bavi ovom problematikom na hrvatskom jeziku. Odgovarajući na u uvodu postavljenja pitanja, u radu se argumentira stav kako podjele raznih mogućnosti miješanja kvalitativnih i kvantitativnih istraživanja zastupljene u metodološkoj literaturi ne moraju nužno biti komplicirane i brojne, posebice razmotre li se u kontekstu odgovarajuće im vrste mješovitog pristupa i odgovora na pitanje miješaju li metode ili metodologije.

Radom se prikazuje kako se mogućnosti miješanja kvalitativnih i kvantitativnih istraživanja mogu podijeliti u dvije osnovne skupine, jednu koja miješa metode i drugu koja miješa i metodologije. Mogućnosti miješanja kvalitativnog i kvantitativnog istraživanja uključene u prvu skupinu su aparadigmatizam, teze o različitim paradigmama primjenjivim specifičnom načinu mješovitog pristupa i metodološki pragmatizam. U radu je argumentiran stav kako su razlike između tih mogućnosti minimalne, tim više što svaka od njih polazi od jedne dominantne paradigme te se koristi sekvencijalnim ili ugrađenim mješovitim nacrtom. Stoga je navedene mogućnosti prve skupine nepotrebno držati odvojenima te in je moguće objediniti nazivom »pristup jedne dominantne paradigme«. Mogućnosti miješanja kvalitativnog i kvantitativnog istraživanja uključene u drugu skupinu su teze o komplementarnim snagama, pristup dijalektičkih teza i teorijski pragmatizam. Kao i kod prve skupine, razlike među pristupima mješovitog istraživanja uključenima u drugu skupinu su minimalne, tim više što se u ovom slučaju svaka od njih koristi konvergentno paralelnim mješovitim nacrtom te polazi od dvije (ili više) paradigme od kojih je svaka jednako važna. Stoga je navedene mogućnosti druge skupine nepotrebno držati odvojenima te ih je moguće objediniti nazivom »pristup ravnopravnih paradigmi

Izbjegavajući preklapanja prisutna u metodološkoj literaturi i predlažući jednostavniju podjelu mogućnosti mješovitih istraživanja, ovim radom nudi se jednostavan vodič za provođenje mješovitog istraživanja. Ovisno o istraživačkim pitanjima i/ili hipotezama, istraživači odabiru najprikladniji mješoviti nacrt koji se potom može smjestiti u jednu od dvije predložene skupine mogućnosti miješanja kvalitativnih i kvantitativnih pristupa

U ponuđenom vodiču polazi se od pretpostavke kako je za mješovito istraživanje, kao i za svako drugo, najvažnije odabrati prikladan mješoviti nacrt, a sve s ciljem odgovaranja na postavljena istraživačka pitanja ili hipoteze. Pri tome se nikako ne umanjuje važnost paradigmi, već se zastupa stajalište da svako, pa tako i mješovito istraživanje, polazi od nekog pogleda na svijet, a opet s ciljem što pri- 
kladnijeg odgovora na istraživačka pitanja ili testiranje hipoteza. Međutim, ponuđenim vodičem izbjegava se dodatno kompliciranje vezano uz pitanje paradigmi mješovitog pristupa. $U$ mješovitom pristupu, istraživači naprosto miješaju ili ne miješaju već postojeće tri osnovne paradigme (pozitivizam, postpozitivizam i konstruktivizam). Dakle, prilikom izrade nacrta mješovitog istraživanja osnovno pitanje nije što i kako s paradigmama, nego pomoću koje vrste nacrta najprikladnije odgovoriti na istraživačka pitanja. Odgovor na pitanje miješaju li se kod odabranog nacrta metode ili metodologije, kao i o kojim se paradigmama u oba slučaja radi, nameće se onda samo po sebi. $U$ vodiču se, stoga, polazi od pretpostavke kako se svako istraživanje, pa tako i ono mješovito, temelji na istraživačkim pitanjima na temelju kojih se onda odabiru metode i pripadajuće im metodologije, a ne obrnuto.

Slijedom navedenog, predloženi vodič temeljen je na pragmatičnom pristupu nastojeći istraživačima mješovitog pristupa olakšati rad i pomoći što kvalitetnije odgovoriti na istraživačka pitanja. Ipak, treba imati u vidu kako se pragmatizam zastupljen u vodiču značajno razlikuje od pragmatizma kao paradigme, ne samo zato što, kako je u ovom radu prikazano, pragmatizam u svojoj osnovi i nije zasebna paradigma, već i zato što je predloženi vodič pragmatičan samo u smislu »alata« za istraživače.

Zaključno, ovim radom pokazuje se kako planiranje i provođenje mješovitog istraživanja najčešće nije onoliko komplicirano koliko to metodološka literatura ponekad sugerira, pogotovo uzme li se u obzir da se prilikom mješovitog istraživanja ipak češće miješaju samo metode, a ne i metodologije. Kao i kod bilo kojeg drugog istraživanja, kod planiranja i provođenja mješovitog istraživanja najvažnije je uspjeti osmisliti i provesti kvalitetno istraživanje, odnosno istraživanje koje će primjereno i temeljito odgovoriti na istraživačka pitanja, bilo miješanjem metoda ili metodologija. Od filozofskih i teorijskih rasprava o paradigmama, za mješovito istraživanje puno je važnije biti dovoljno vješt ne samo adekvatno odgovoriti na istraživačka pitanja, već i pomaknuti istraživanje od samo deskriptivnog (ukoliko se radi o dominantno kvalitativnom istraživanju) ili samo ateoretskog (ukoliko se radi o dominantno kvalitativnom istraživanju) ili pak deskriptivno/ateoretskog (ukoliko se radi o mješovitom pristupu).

Kvalitetno istraživanje, bilo ono kvalitativno, kvantitativno ili mješovito je ono koje uspijeva testirati i/ili razvijati teorije ili pak odgovoriti na pitanja o vezama među pojavama ili njihovoj uzročnosti. S obzirom da su dobra mješovita istraživanja samo nadogradnja kvalitetnih i rigoroznih kvalitativnih i kvantitativnih istraživanja koja nadilaze razinu deskripcije, ovaj rad u svojoj konačnici istraživače poziva na dvije stvari: 1) pomicanje nemješovitih istraživanja od samo deskriptivnih i ateoretskih prema rigoroznim i kvalitetnim istraživanjima koja ispituju veze među pojavama, uzroke pojava, testiraju ili razvijaju teorije kao preduvjet za razvoj

\section{8 članci}


mješovitih istraživanja; 2) pragmatičniji i konkretniji pristup istraživača u planiranju mješovitih istraživanja uz izbjegavanje pretjeranih teorijskih rasprava o raznim mogućnostima mješovitog pristupa, s ciljem češćeg provođenja mješovitih istraživanja u hrvatskim društvenim znanostima. Ovaj rad nudi praktičan vodič za potonje.

\section{LITERATURA}

1. Apolo Peter, K. (2010). The interpretation and use of mixed methods research within programe evaluation practice. Stellenbosh: Faculty of Arts.

2. Betzner, A. E. (2008). Pragmatic and dialectic mixed method approaches: An empirical comparison. Doctoral dissertation. Minnesota: Faculty of Graduate School.

3. Bisman, J. E. \& Highfield, C. (2012). The road less travelled: An overview and example of constructivist research in accounting, Australasian accounting. Business and Finance Journal, 6 (5), 3-22.

4. Brewer, J. \& Hunter, A. (1989). Multimethod research: A synthesis of styles. Newbury Park, CA: Sage Publications.

5. Buć, S. (2007). Model upravljanja rizicima kod javnih projekata. Magistarski rad. Varaždin: Fakultet organizacije i informatike Varaždin.

6. Burke Johnson, R. \& Onwuegbuzie, A. J. (2004). Mixed methods research: A research paradigm whose time has come. Educational Researcher, 33 (7), 14-26.

7. Burke Johnson, R., Onwuegbuzie, A. J. \& Turner, L. A. (2007). Toward a definition of mixed methods research. Journal of Mixed Methods Research, 1 (2), 112-133.

8. Creswell, J. W. (2009). Research design: Qualitative, quantitative, and mixed methods approaches (3rd edition). Los Angeles: Sage Publications, Inc.

9. Creswell, J. W. \& Plano Clark, V. L. (2007). Designing and conducting mixed methods research. Thousand Oaks, CA: Sage Publication.

10. Creswell, J. W. \& Plano Clark, V. L. (2011). Designing and conducting mix methods research (2nd edition). Thousand Oaks, CA: Sage Publication

11. Creswell, J. W. (2014). Research design: Qualitative, quantitative, and mixed methods approaches. (4th edition.) Thousand Oaks, CA: Sage Publication.

12. Denzin, N. K. \& Lincoln, Y. S. (1994). Introduction: Entering the field of qualitative research. In: Denzin, N. K. \& Lincoln, Y. S. (eds.), Handbook of qualitative research. Thousand Oaks: Sage Publication, 1-17.

13. Denzin, N. K. \& Lincoln, Y. S. (2011). The SAGE handbook of qualitative research. Thousand Oaks, CA: Sage Publication

14. de Waal, C. (2005). On pragmatism. Belmont, CA: Wadsworth Press

15. Este, D., Sitter, K. \& Maclaurin, B. (2009). Using mix methods to understand youth resilience. In: Liebenberg, L. \& Ungar, M. (eds.), Researching resilience. Toronto: University of Toronto Press, 201-224. 
16. Freshwater, D. \& Cahill, J. (2013). Paradigms lost and paradigms regained. Journal of Mixed Methods Research, 7 (3), 3-5.

17. Garcia, M. R. (2015). Reality construction, communication and daily life - An approach to Thomas Lukmann work. Sao Paulo, 38 (2), 19-36.

18. Giddings, L. S. \& Grant, B. M. (2007). A Trojan horse for positivism? A critique of mixed methods research. Advances in Nursing Science, 30 (1), 52-60.

19. Giljević, T. (2014). Utjecaj organizacijskih varijabli na upravnu koordinaciju. Doktorska disertacija. Zagreb: Pravni fakultet, Sveučilište u Zagrebu.

20. Giljević, T. (2015). Utjecaj organizacijskih varijabli na upravnu koordinaciju: Ministarstvo uprave kao studija slučaja. Hrvatska i komparativna javna uprava,15 (4), 875-908.

21. Greene, J. C. (2007). Mixed methods in social inquiry. San Francisco, CA: John Wiley \& Sons.

22. Greene, J. C. (2008). Is mixed methods social inquiry a distinctive methodology? Journal of Mixed Methods Research, 2 (1), 7-22.

23. Guba, E. G. \& Lincoln, Y. S. (1994). Competing paradigms in qualitative research. In: Denzin, N. K. \& Lincoln, Y. S. (eds.), Handbook of qualitative research. Thousand Oaks, CA: Sage, 105-117.

24. Guba, E. G. \& Lincoln, Y. S. (2005). Paradigmatic controversies, contradictions, and emerging confluences. In: Denzin, N. K. \& Lincoln, Y. S. (eds.), The sage handbook of qualitative research (3rd edition). Thousand Oaks: Sage, 191-215.

25. Hall, R. (2012). Mixed methods: In search of a paradigm. In: Le, T. \& Le, Q. (eds.), Conducting research in changing and challanging world. New York: Nova Science Publishers, 71-78.

26. Kisovar Ivanda, T. \& Batarelo-Kokić, I. (2012). Povezanost zavičajnog identiteta i muzejskog iskustva učenika. Magistra iadertina, 7 (7), 7-19.

27. Kisovar-Ivanda, T. (2013). Dimenzije učeničke percepcije muzejskih sadržaja i dob učenika. Pedagogijska istraživanja, 10 (2), 343-360.

28. Kisovar-Ivanda, T. (2014). Modeliranje muzejskih sadržaja i interakcijske aktivnosti učenika u muzejskom okruženju. Školski vjesnik, 63 (1-2), 53-69.

29. Mackenzie, N. \& Knipe, S. (2006). Research dillemas: Paradigms, methods and methodology. Issues in Educational Research, 16 (2), 193-205.

30. Mašanović, M. (2011). Ocjena zdravstvenih potreba starije populacije u Dubrovačkom primorju kombiniranom kvalitativno-kvantitativnom metodologijom. Magistarski rad. Zagreb: Medicinski fakultet.

31. McGregor, S. L. T. \& Murnane, J. A. (2010). Paradigm, methodology and method: Intellectual integrity in consumer scholarship. International Journal of Consumer Studies, 34 (4), 419-427.

32. Mertens, M. D. (2010). Philosophy in mixed methods teaching: The transformative paradigm as illustration. International Journal of Multiple Research Approaches, 4 (1), 9-18.

\section{0 članci}


33. Mejovšek, M. (2013). Metode znanstvenog istraživanja u društvenim i humanističkim znanostima. Jastrebarsko: Naknada Slap.

34. Morgan, D. L. (2007). Paradigms lost and pragmatism regained. Methodological implications of combining qualitative and quantitative methods. Journal of Mixed Methods Research, 1 (1), 48-76.

35. Morse, J. M. (2003). A review committee's guide to evaluating qualitative proposal. Qualitative Health Research, 13 (6), 833-851.

36. Plano Clark, V., Huddleston-Casas, C., Churchill, S., O'Neil Green, D. \& Garrett, A. (2008). Mix methods approaches in family science research. Journal of Family Issuess, 29 (11), 1543-1566.

37. Ratkajec Gašević, G. (2013). Spremnost mladih osoba na promjenu tijekom posebne obveze uključivanja u individualni ili grupni psihosocijalni tretman u savjetovalištu za mlade. Doktorska disertacija. Zagreb: Studijski centar socijalnog rada, Pravni fakultet, Sveučilište u Zagrebu.

38. Rukavina, S. (2014). Utjecaj mrežnog okruženja na suradničko učenje u visokoškolskoj nastavi. Doktorska disertacija. Zagreb: Filozofski fakultet.

39. Schwandt, T. A. (2001). Dictionary of qualitative inquiry (2nd edition). Thousand Oaks: Sage.

40. Stanić, S. (2011). (Post)socijalnost u suvremenom potrošačkom prostoru. Sociologija i prostor, 49, 189 (1), 3-23.

41. Symonds, J. E. \& Gorard, S. (2008). The death of mixed methods: Research labels and their casualties. The British Educational Research Association Annual Conference, Heriot Watt University, Edinburgh, September, 3-6.

42. Tafra-Vlahović, M. (2011). Odnosi s javnostima i korporacijska odgovornost u Hrvatskoj. Medianali, 5 (10), 107-124.

43. Tashakkori, A. \& Teddlie, C. (1998). Mixed methodology: Combining qualitative and quantitative approaches. Thousand Oaks, CA: Sage.

44. Tashakkori, A. \& Teddlie, C. (2003). Handbook of mixed methods in social and behavioral research. Thousand Oaks, CA: Sage Publications.

45. Teddlie, C. \& Tashakkori, A. (2009). Foundations of mixed methods research. Thousand Oaks, CA: Sage Publications. 
Ljetopis socijalnog rada 2017., 24 (1), 7-32.

\title{
Ivana Sekol
}

Josip Juraj Strossmayer University in Osijek

Faculty of Education

Department of Social Sciences

\author{
Ivana Maurović \\ University of Zagreb \\ Faculty of Education and Rehabilitation Sciences \\ Department of Behavioral Disorders
}

\section{MIXING QUANTITATIVE AND QUALITATIVE RESEARCH APPROACHES IN SOCIAL SCIENCE - MIXING METHODS OR METHODOLOGY?}

\begin{abstract}
While in the western world the mixed-methods approach in social sciences is becoming more popular, in Croatian social sciences mixed methods research is still scarce. This is probably due to the complexity of mixed-methods research and numerous questions related to it. The most common questions that researchers need to answer prior to conducting a mixed methods study are: 1) will my research mix methods or methodologies?, 2) if it will mix methodologies, and not only methods, which paradigm(s) and research design will I use?, and 3) is it at all possible to combine inherently different paradigms? The main aim of this paper is to examine whether there is a strategy to simplify the way the existing literature describes numerous possibilities of combining qualitative and quantitative research - especially in terms of the type of mix-method research and whether each type mixes methods or methodologies. Following a literature review on the characteristics of mixed-methods approach, types of mix-method design and paradigmatic challenges, this paper proposes a simplified model of the existing possibilities for combining qualitative and quantitative research. The model argues that, depending on their research questions, all mixed-methods attempts can be divided into one of the two main categories: one that mixes methods, and the other that mixes methodologies. The proposed model offers a straightforward tool for planning a mixed-methods research.
\end{abstract}

Key words: mix method approach, combining, methods, methodologies.

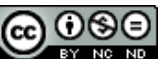

Međunarodna licenca / International License:

Creative Commons Attribution-NonCommercial-NoDerivatives 4.0.

\section{2 članci}

